\title{
A complete dynamical ozone budget measured in the tropical marine boundary layer during PASE
}

\author{
Stephen A. Conley • Ian C. Faloona • Donald H. Lenschow • Teresa Campos • \\ Clifford Heizer • Andrew Weinheimer • Christopher A. Cantrell • Roy L. Mauldin III • \\ Rebecca S. Hornbrook • Ilana Pollack • Alan Bandy
}

Received: 16 February 2011 / Accepted: 18 July 2011 /

Published online: 19 August 2011

C The Author(s) 2011. This article is published with open access at Springerlink.com

\begin{abstract}
The Pacific Atmospheric Sulfur Experiment (PASE) was a field mission that took place aboard the NCAR C-130 airborne laboratory over the equatorial Pacific Ocean near Christmas Island (Kirimati, Republic of Kiribati) during August-September, 2007. Eddy covariance measurements of the ozone fluxes at various altitudes above the ocean surface, along with simultaneous mapping of the horizontal gradients provided a unique opportunity to observe all of the dynamical components of the ozone budget in this remote marine environment. The results of six daytime and two sunrise flights indicate that vertical transport into the marine boundary layer from above and horizontal advection by the tradewinds are both important source terms, while photochemical destruction consisting of $82 \%$ photolysis (leading to $\mathrm{OH}$ production), $11 \%$ reaction with $\mathrm{HO}_{2}$, and $7 \%$ reaction with $\mathrm{OH}$ provides the main sink. The overall photochemical lifetime of ozone in the marine boundary layer was found to be 6.5 days. Ocean uptake of ozone was observed to be fairly slow (mean deposition velocity of $0.024 \pm 0.014 \mathrm{~cm} \mathrm{~s}^{-1}$ ) accounting for a diurnally averaged loss rate that was $\sim 30 \%$ as large as the net photochemical destruction. From the measurement of deposition velocity an ozone reactivity of $\sim 50 \mathrm{~s}^{-1}$ in seawater is inferred. Due to the unprecedented measurement accuracy of the dynamical budget terms,
\end{abstract}

S. A. Conley $(\bowtie) \cdot$ I. C. Faloona

Department of Land, Air and Water Resources, University of California, Davis, CA, USA

e-mail: saconley@ucdavis.edu

D. H. Lenschow $\cdot$ T. Campos • C. Heizer - A. Weinheimer • C. A. Cantrell • R. L. Mauldin III •

R. S. Hornbrook

Atmospheric Chemistry Division, National Center for Atmospheric Research, Boulder, CO, USA

R. L. Mauldin III

Department of Physics, University of Helsinki, Helsinki 00014, Finland

I. Pollack

Chemical Sciences Division, National Oceanographic and Atmospheric Administration, Boulder, CO, USA

A. Bandy

Department of Chemistry, Drexel University, Philadelphia, PA, USA 
unobserved photochemistry was able to be deduced, leading to the conclusion that $3.9 \pm 3.0 \mathrm{ppt}$ (parts per trillion by volume) of $\mathrm{NO}$ is present on average in the daytime tropical marine boundary layer, broadly consistent with several previous studies in similar environments. It is estimated, however, that each ppt of BrO hypothetically present would counter each ppt of NO above the requisite $3.9 \mathrm{ppt}$ needed for budget closure. The long-term budget of ozone is further analyzed in the buffer layer, between the boundary layer and free troposphere, and used to derive an entrainment velocity across the trade wind inversion of $0.66 \pm 0.38 \mathrm{~cm} \mathrm{~s}^{-1}$.

Keywords Ozone $\cdot$ Marine boundary layer $\cdot$ Christmas Island $\cdot$ Tropics $\cdot$ Turbulence

\section{Introduction}

Ozone is of fundamental importance in the troposphere, both because of its health effects on humans, other animals, and terrestrial plant life but further because of its potential influence on the global climate. Tropospheric ozone is the third largest contributor to greenhouse gas warming (Hansen et al. 2007). Produced as a secondary pollutant during the atmospheric oxidation of $\mathrm{CO}$ and hydrocarbons in the presence of $\mathrm{NO}_{\mathrm{x}}$, ozone is readily photolyzed, providing the principal source of hydrogen oxide radicals $\left(\mathrm{HO}_{\mathrm{x}}=\mathrm{OH}+\mathrm{HO}_{2}\right)$, which drive the oxidation of most biogenic and anthropogenic reduced gases (Johnson et al. 1990). Ozone is further destroyed by reaction with the very same hydrogen oxide radicals and is therefore intimately linked to the oxidative capacity, and thus the "health", of the atmosphere. Modeling investigations indicate that the lower tropical marine troposphere supports the largest net photochemical $\mathrm{O}_{3}$ loss rates anywhere on Earth (Horowitz et al. 2003;Crutzen et al. 1999) due to abundant actinic radiation (low latitudes and low stratospheric ozone column), ample water vapor, and negligible $\mathrm{NO}_{\mathrm{x}}$. Consequently this region is responsible for the great majority of global oxidation of the important carbon cycle gasses, $\mathrm{CO}$ and $\mathrm{CH}_{4}$ (Crutzen et al. 1999).

The diurnal cycle of ozone differs significantly between continental and marine boundary layers. Over the continents substantial amounts of $\mathrm{NO}_{\mathrm{x}}$ from internal combustion, along with reactive hydrocarbons from terrestrial vegetation and industry provide a ready mix for ozone production. Furthermore, dry deposition rates are roughly an order of magnitude higher over land surfaces than over the oceans (Ganzeveld and Lelieveld 1995), thus ozone concentrations tend to rise and fall with the sun (delayed by a few hours) reaching a maximum in the early afternoon coincident with the maximum height of the mixed layer (Kolev et al. 2008) and then decaying back to a predawn minimum near the surface due to surface uptake under a more shallow nocturnal boundary layer. The theory explaining diurnal ozone cycles in remote marine boundary layers (MBLs) was first described by Liu et al. (1983), although the authors claim to have observed "virtually no diurnal variations." The general MBL balance was nonetheless established as the result of entrainment of ozone rich air aloft, or large scale horizontal advection into the tropics from higher latitudes, balanced by net photochemical destruction throughout the day along with continuous, gradual dry deposition to the ocean. This pattern has been observed and explained thusly in numerous experiments since (Piotrowicz et al. 1986; Johnson et al. 1990; Thompson et al. 1993; Heikes et al. 1996; Singh et al. 1996; Faloona et al. 2005). Liu et al. (1983) found a net ozone photochemical loss rate of 2 ppv day ${ }^{-1}$, with roughly $70 \%$ of the loss coming from reaction of excited oxygen, $\mathrm{O}\left({ }^{1} D\right)$, with water vapor to form hydroxyl $(\mathrm{OH})$ and $30 \%$ coming from reaction of ozone with $\mathrm{HO}_{2}$.

The source of ozone entrained into the remote MBL is from broad regions of tropospheric subsidence in conjunction with direct injection from the stratosphere and/or net in-situ photochemical production due to $\mathrm{NO}_{\mathrm{x}}$ from lightning, biomass burning, and/or lofted fossil 
fuel emissions (Jacob et al. 1996; Staudt et al. 2003). De Laat and Lelieveld (2000) point out that in many regions horizontal advection of ozone from distant continental sources could provide adequate $\mathrm{O}_{3}$ to match the daytime photochemical destruction in the MBL. More recently, reactive bromine has been implicated in the remote MBL ozone balance (Read et al. 2008; Hausmann and Platt 1994). Although quantifying the exact magnitude of halogen chemistry is difficult due to the uncertainty of the heterogeneous source reactions, the modeling work of von Glasow et al. (2002) and Yang et al. (2005) suggest that somewhere on the order of $5-30 \%$ of total ozone destruction could be due to reactive halogens in the remote MBL, and the observational study reported in Read et al. (2008) point toward $\sim 25 \%$ of the photochemical ozone losses coming from $\mathrm{BrO} / \mathrm{IO}$ reactions in the tropical Atlantic.

The Pacific Atmospheric Sulfur Experiment (PASE) was an airborne field mission that took place aboard the NCAR C-130 over the equatorial Pacific Ocean near Christmas Island (Kirimati, Republic of Kiribati) during August-September, 2007. A series of tightly focused flights over the lower marine troposphere yielded unprecedented accuracy in determining trace gas budgets. Eddy covariance measurements of the ozone fluxes at various altitudes above the ocean surface, along with simultaneous mapping of its horizontal gradient, and $\mathrm{HO}_{\mathrm{x}}$ species abundances provided a unique opportunity to observe all of the main components of the ozone budget in this remote marine environment. The results of six daytime and two sunrise flights indicate that vertical transport into the boundary layer from above and horizontal advection in the trade winds are equally important source terms, while photochemical destruction provides the dominant sink $(80 \%$ photolysis followed by reaction with water to make $\mathrm{OH}, 13 \%$ reaction with $\mathrm{HO}_{2}$, and $7 \%$ reaction with $\mathrm{OH}$.) Ocean uptake of ozone was fairly slow (mean deposition velocity of $0.024 \pm 0.014 \mathrm{~cm} \mathrm{~s}^{-1}$ ) accounting for a diurnally averaged loss approximately one-quarter the magnitude of net photochemical destruction. The net photochemical desctruction rendered an ozone lifetime of 6.5 days in the remote MBL of the equatorial Pacific.

\section{Methods}

\subsection{Flight pattern}

Airborne measurement platforms provide a unique opportunity to sample the atmosphere at multiple heights over a broad area in relatively short periods of time. During PASE, flights were structured to allow vertical flux measurements from the minimum safe altitude ( $\sim 30 \mathrm{~m}$ above the ocean surface during daylight) to the trade wind inversion (TWI, $\sim 1,300 \mathrm{~m}$ ), and rapid profiling well into the lower free troposphere (FT). Although this type of flight strategy has been executed in the past, PASE was the first mission to provide a repeated range of MBL flux measurements coincident with $\mathrm{HO}_{\mathrm{x}}$ species and hence achieve unprecedented accuracy in the budgets of ozone, and sulfur species such as DMS (Conley et al. 2009) and $\mathrm{SO}_{2}$ (Faloona et al. 2009). A total of 14 research flights were conducted using NSF's National Center for Atmospheric Research (NCAR) C-130 between August 7 and September 4, 2007, but only eight are considered here. Flights RF09 and RF10 were excluded due to malfunction of the inertial navigation system. RF04, was designed to perform cloud penetrations in deeper convection near the ITCZ, and consequently did not permit a careful scalar budget assessment, and three other flights were subject to instrumental/logistical limitations of one kind or another.

Typical flights consisted of three stacks spanning $\sim 7 \mathrm{~h}$ on station. Each stack was made up of a series of 30 min legs: usually one in the surface layer $(\sim 30 \mathrm{~m})$, one in the middle of the MBL ( 200 m), one at the top of the MBL ( $\sim 500 \mathrm{~m})$ and another in the overlying buffer 
layer (BuL) (usually between 700 and 1,200 m altitude). Each stack also included a 610 min vertical profile which usually began near the lowest level leg altitude $(\sim 30 \mathrm{~m})$ and ended above the TWI $(\sim 2,000 \mathrm{~m})$. The level legs were typically $30 \mathrm{~min}$ long and the profile legs varied between 6 and $10 \mathrm{~min}$. NCAR safety rules required ascending to higher altitudes before making turns during the lowest legs, consequently, the lower boundary layer (LBL) legs were separated into two legs of roughly $15 \mathrm{~min}$, and then combined into one equivalent LBL leg. Flight legs consisted of either a continuous 30-min circle, or a chevron pattern consisting of two $15 \mathrm{~min}$ legs with a $60^{\circ}$ turn in the middle. The orientation of the legs was chosen so that the mean wind bisected the angle of the chevron pattern. Further discussion of the flight strategies can be found in Conley et al. (2009).

\subsection{Boundary layer budget}

The methodology of airborne scalar budget accounting was pioneered by Lenschow et al. (1980), using water vapor, potential temperature, and ozone. The budget of a scalar in a turbulent fluid is derived from the principle of mass conservation and Reynolds averaging to derive a budget, or tendency, equation for the mean. For a scalar, $c$, with in-situ production and loss rates, $P$ and $L$, mixing within a wind field $\mathbf{u}=(u, v)$, the budget equation is:

$$
\frac{\partial c}{\partial t}=-\nabla \cdot(c \mathbf{u})-D_{c} \nabla^{2} c+P-L
$$

with $D_{c}$ representing the gaseous diffusion coefficient of the scalar in air. In a turbulent wind field, the budget equation is expanded by Reynolds averaging Eq. 1 neglecting molecular diffusion in the high Corrsin number flow (Corrsin number $=U l / D_{c}$, where $U$ is a characteristic wind speed and $l$ is a length scale) of the atmospheric boundary layer (Wyngaard 2010), and assuming horizontal homogeneity of the second-moment statistics $(\partial / \partial x, \partial / \partial y=0)$, incompressible flow $(\nabla \cdot \mathbf{u}=0)$, and a negligible mean vertical wind. Given these simplifying assumptions, the scalar mean, $\bar{c}$, budget equation becomes:

$$
\frac{\partial \bar{c}}{\partial t}=-\bar{u} \frac{\partial \bar{c}}{\partial x}-\bar{v} \frac{\partial \bar{c}}{\partial y}-\frac{\partial}{\partial z}\left(\overline{w^{\prime} c^{\prime}}\right)+\bar{P}-\bar{L}
$$

where turbulent covariances between the chemical species involved in $\mathrm{P}$ and $\mathrm{L}\left(\mathrm{NO}, \mathrm{HO}_{2}\right.$, actinic radiation, etc.) are neglected because of the small Damköhler number (a ratio of turbulent mixing to chemical time scales) of the flow (de Arellano et al. 2004) and the presumed absence of any nearby localized sources or sinks of these species (Krol et al. 2000).

\subsection{Gradients in space \& time}

The functional form for the ozone mixing ratio $(c)$ is $c=f(x, y, z, t)$, where the variables have their standard meanings. Expanding $f$ in a Taylor series about some known point, chosen for convenience to be an arbitrary origin $(0,0,0,0)$ and retaining only first order terms yields:

$$
f(x, y, z, t) \cong f_{0}+\frac{\partial f}{\partial x} x+\frac{\partial f}{\partial y} y+\frac{\partial f}{\partial z} z+\frac{\partial f}{\partial t} t
$$

Each flight includes approximately $7 \mathrm{~h}$ of airborne data on station within the MBL. To estimate the partial derivatives in Eq. 3, we perform an ordinary least squares (OLS) regression to minimize the deviation between the ozone mixing ratio given by Eq. 3 with the actual 
measured mixing ratio. A comparison of the mixing ratio predicted using the linear fit with the actual measurements is shown in Fig. 1 for RF02. Inspection of Fig. 1 reveals that the regression reproduces the daily variation quite well. The ' $\mathrm{V}$ ' shapes in each stack result from flying the circular pattern (switched to the chevron pattern after RF02) within a region with an approximately linear horizontal gradient while the long term decrease shows the effects of photochemical destruction throughout the day. For the day flights considered here, the average $R^{2}$ value for the fits was 0.66 . The first two linear coefficients in (3) are used to derive the mean horizontal advection term in the budget (when scaled by the mean wind components), and the last coefficient represents the overall time rate of change of ozone - the left hand side of Eq. 2 .

\subsection{Measurements}

Two independent instruments were used to measure ozone aboard the C-130 aircraft during PASE; both measurements are utilized in this analysis. The first instrument (TECO) is a commercial UV-absorption based ozone analyzer (Thermo Environmental Instruments, model $49 \mathrm{c}$ ) with a $20 \mathrm{~s}$ response time and a $1 \mathrm{ppv}$ detection limit and precision. The second is the NCAR fast-response $\left(5 \mathrm{~Hz}\right.$ ) ozone instrument employing $\mathrm{NO}-\mathrm{O}_{3}$ chemiluminescence (CL) detection (Eastman 1977; Pearson 1980). The detector of the CL instrument is identical to the $1-\mathrm{sec}$ instrument reported by Ridley et al. (1992). Addition of a pumped bypass flow inlet allows improved instrument time resolution to $200 \mathrm{~ms}$ for PASE. A pressure controlled (200 Torr) bypass flow of ambient air varying between 800 and 3000 standard cubic centimeters per minute $(\mathrm{sccm})$ as a function of aircraft altitude is generated using a pressure controller (MKS, model 640A) configured for downstream control and two small diaphragm pumps (Vaccubrand, model MD1) connected in parallel. A tee positioned between the pressure controller and diaphragm pumps directs a portion of the air sample to the CL detector. A sample flow of $500 \mathrm{sccm}$ and a pressure of 10 Torr are maintained in the detector using a stainless steel metering valve (Hoke 1300 Series) thermally stabilized to $35^{\circ} \mathrm{C}$, a throttling pressure control valve (MKS, model 153D), and a scroll pump (Synergy Vacuum, ISP-90). A mass flow meter (Sierra, model 830D) positioned in-line of the sample flow path monitors the flow rate through the detector. Both the CL and TECO instruments were routinely calibrated on the ground between flights using a UV-based ozone generator/ analyzer (Thermo Environmental Instruments, model 49PS). The accuracy of the ozone CL

Fig. 1 Comparison of $60-\mathrm{sec}$ TECO ozone measurements (blue) versus least squares regression (green) in units of ppv (parts per billion by volume) for all the MBL data from RF02. $R^{2}$ for the fit is 0.88

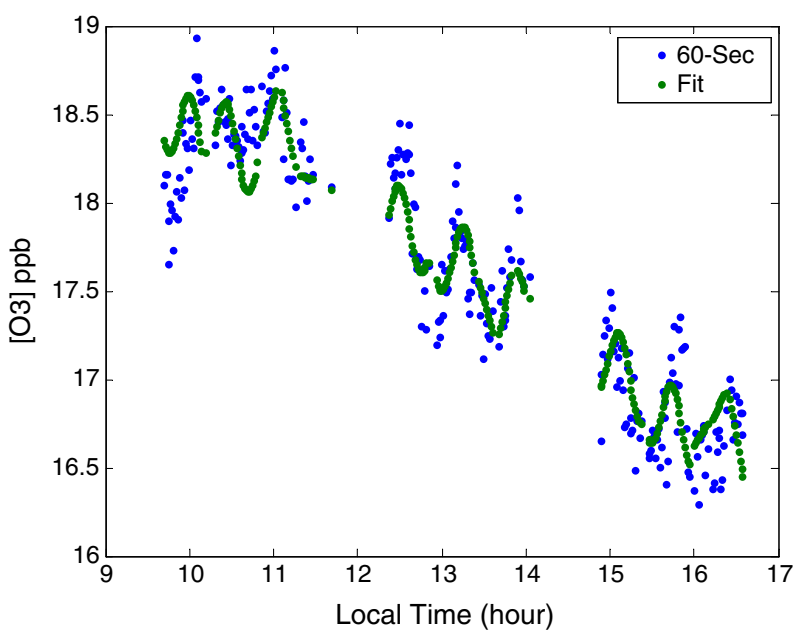


measurement is $\pm 2 \mathrm{ppv}$, corresponding to the accuracy of the transfer calibration unit. The main advantage of the CL measurement for this analysis lies in its high sensitivity $(\sim 2,200 \mathrm{~Hz}$ per ppv), precision $( \pm 0.25 \mathrm{ppv}$ over a $10 \mathrm{~s}$ average $)$, detection limit (0.02 ppv), and time response $(0.2 \mathrm{~s})$. The CL measurements are used only in computing eddy covariance fluxes while the TECO (slow rate) measurements are used for estimates of horizontal gradients and temporal trends which transpire gradually during each flight. Notice that any systematic errors in the calibration of the ozone measurements will cancel out of all terms other than the photochemical production, which is independent of ozone amount, when applied to Eq. 2. A simple regression analysis of $60 \mathrm{~s}$ averaged TECO (lagged by $16 \mathrm{~s}$ to account for the flow/response delay) and CL data from the entire mission yielded correspondence between the two measurements to within $2 \%-\mathrm{CL}=(0.981 \pm 0.26) \mathrm{TECO}+(0.97 \pm 0.48) \mathrm{ppv}$.

The time lag between the ozone measurement and vertical wind speed was estimated by finding the lag time of the greatest correlation, varying between $\pm 1 \mathrm{~s}$. Turbulent fluxes were calculated via eddy covariance using an averaging interval of $200 \mathrm{~s}$ (22 km flight distance). Conley et al. (2009) described the selection of the averaging interval in detail.

$\mathrm{OH}, \mathrm{HO}_{2}$ and $\mathrm{RO}_{2}$ (organic peroxy radicals, where $\mathrm{R}$ represents any alkyl group) were measured using the NCAR 4-channel chemical ionization mass spectrometer (CIMS) which has been described previously (Mauldin et al. 2003; Cantrell et al. 2003a, b). The inlet for measuring $\mathrm{HO}_{2}$ and $\mathrm{RO}_{2}$ was modified prior to the PASE experiment, and now includes an oxygen dilution modulation step that allows for separated measurements of $\mathrm{HO}_{2}$ and $\mathrm{HO}_{2}+\mathrm{RO}_{2}$ to be made once per minute (Hornbrook et al. 2011). Briefly, by alternating the ratio of $[\mathrm{NO}] /\left[\mathrm{O}_{2}\right]$ in the inlet with added $\mathrm{NO}$ and either $\mathrm{O}_{2}$ or $\mathrm{N}_{2}$, either $\mathrm{HO}_{2}$ or both $\mathrm{HO}_{2}$ and $\mathrm{RO}_{2}$ are chemically converted to $\mathrm{OH}$. The resulting $\mathrm{OH}$ reacts with added $\mathrm{SO}_{2}$ to form $\mathrm{H}_{2} \mathrm{SO}_{4}$, which is quantitatively measured using CIMS. Similarly, on the $\mathrm{OH}$ inlet, ambient $\mathrm{OH}$ is measured by first converting it to $\mathrm{H}_{2}{ }^{34} \mathrm{SO}_{4}$ using isotopically-labeled ${ }^{34} \mathrm{SO}_{2}$ and the $\mathrm{H}_{2}{ }^{34} \mathrm{SO}_{4}$ is measured using CIMS.

\subsection{Horizontal advection}

Figure 2 shows the tropospheric mean ozone (Ziemke et al. 2006) measured by the Total Ozone Mapping Spectrometer (TOMS) for August 2007. Inspection of Fig. 2 reveals that the PASE study region is an area of low ozone with significantly higher ozone levels upwind (akin to the vast majority of the Central and Eastern Pacific). While the mean ozone in the flight region is patchy, allowing for the advective contribution to switch signs from flight to flight, the overall mean during the entire project is expected to be positive, as is true generally for the entire troposphere (Fig. 2). From the multiple regression fit of Eq. 3, we calculate an average gradient of $-0.12 \mathrm{ppv}$ per degree along the mean MBL trade wind direction (i.e. higher concentrations to the east/southeast). For the eight PASE flights used in this analysis, the average advection term is $48 \mathrm{ppt} \mathrm{h}^{-1}$, translating to a daily ozone increase of $1.2 \mathrm{ppv} \mathrm{d}^{-1}$. However, on three flights the advection term contributed to a decrease of ozone locally (Table 1). Natural synoptic variability in convective activity, entrainment, and lower tropospheric subsidence can reasonably be expected to establish mesoscale gradients within the MBL that might lead to negative advection on some days. Although the TOMS satellite data represents a column month-long average, the overall pattern of advection from the anthropogenically influenced continents appears to correspond quite well with the insitu flight data and, indeed, the observed tropospherically averaged gradient is similar in magnitude. Notice, however, that even in the remote MBL it is critically important to 


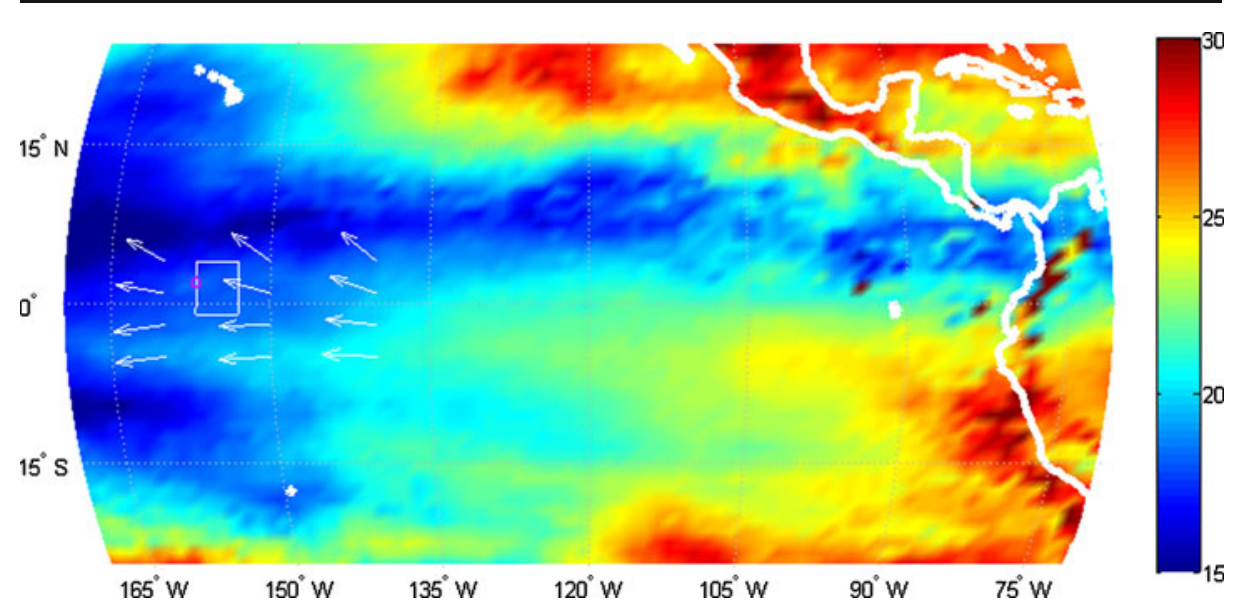

Fig. 2 TOMS Tropospheric mean ozone for month of August 2007 (ppv). Vectors represent mean winds in the region as observed by QuikSCAT, and the box depicts the general study area of PASE

consider horizontal advection because on any given flight it can be of comparable magnitude to the other leading terms of the budget (e.g. RF2 and RF14.)

\subsection{Error estimates}

Error estimates for each of the budget terms was derived from the regression analysis of at least $7 \mathrm{~h}$ of data for each flight. The advection and rate of change terms used 1-min averages, while the flux estimates used $200 \mathrm{~s}$ averages (selected to include all of the relevant scales of motion). Standard errors of the coefficients estimated by the ordinary least squares (OLS) fit were then used to estimate the error in each term, and the resulting errors were added

Table 1 Ozone budget terms for the six daytime flights and the post-dawn hours of the two sunrise flights (RF06 \& RF13), along with the mean of each group. Budget columns are in sequence (ppbv $\mathrm{h}^{-1}$ ): Observed $\mathrm{O}_{3}$ rate of change, observed flux divergence, observed horizontal advection, total photochemical loss to $\mathrm{HO}_{2}$, $\mathrm{OH}$, and to photolysis with subsequent reaction with water vapor, and the net budget residual (imbalance). Estimated error is shown as uncertainty $( \pm)$ for each term. The last two columns show the observed deposition velocity $\left(\mathrm{mm} \mathrm{sec}^{-1}\right)$ and the mean MBL mixing ratio (ppb)

\begin{tabular}{llllllll}
\hline $\mathrm{RF}$ & $\begin{array}{l}\text { Observed } \\
\text { trend } \\
\left.(\mathrm{ppbv} \mathrm{h})^{-1}\right)\end{array}$ & $\begin{array}{l}\text { Flux divergence } \\
(\mathrm{ppbv} \mathrm{h})^{-1}\end{array}$ & $\begin{array}{l}\text { Horizontal } \\
\text { advection } \\
\left(\mathrm{ppbv} \mathrm{h}^{-1}\right)\end{array}$ & $\begin{array}{l}\text { Photochemical } \\
\text { loss }\left(\mathrm{ppbv} \mathrm{h}^{-1}\right)\end{array}$ & $\begin{array}{l}\text { Net residual } \\
\left(\mathrm{ppbv} \mathrm{h}^{-1}\right)\end{array}$ & $\begin{array}{l}\mathrm{V}_{\mathrm{d}} \\
\left(\mathrm{mm} \mathrm{s}^{-1}\right)\end{array}$ & $\begin{array}{l}{\left[\mathrm{O}_{3}\right]} \\
(\mathrm{ppb})\end{array}$ \\
\hline 1 & $-.310 \pm .032$ & $.034 \pm .066$ & $-.100 \pm .014$ & $-.348 \pm .040$ & $.105 \pm .085$ & $.216 \pm .068$ & 16.5 \\
2 & $-.200 \pm .032$ & $-.054 \pm .051$ & $.178 \pm .016$ & $-.364 \pm .041$ & $.040 \pm .074$ & $.045 \pm .060$ & 17.6 \\
5 & $-.228 \pm .030$ & $.094 \pm .031$ & $-.004 \pm .019$ & $-.372 \pm .043$ & $.055 \pm .063$ & $.126 \pm .041$ & 18.1 \\
8 & $.056 \pm .049$ & $.129 \pm .044$ & $.121 \pm .036$ & $-.317 \pm .037$ & $.122 \pm .084$ & $.208 \pm .124$ & 15.7 \\
12 & $-.030 \pm .061$ & $.027 \pm .120$ & $.201 \pm .020$ & $-.437 \pm .051$ & $.178 \pm .145$ & $.453 \pm .091$ & 19.3 \\
14 & $-.326 \pm .035$ & $.059 \pm .029$ & $-.224 \pm .027$ & $-.364 \pm .042$ & $.203 \pm .068$ & $.158 \pm .063$ & 17.7 \\
Mean & $-.173 \pm .041$ & $.048 \pm .065$ & $.029 \pm .023$ & $-.367 \pm .043$ & $.117 \pm .091$ & $.201 \pm .077$ & 17.5 \\
6 & $.074 \pm .070$ & $.055 \pm .047$ & $.108 \pm .021$ & $-.130 \pm .047$ & $.042 \pm .088$ & $.302 \pm .037$ & 17.4 \\
13 & $.228 \pm .072$ & $.264 \pm .086$ & $.106 \pm .041$ & $-.176 \pm .086$ & $.033 \pm .120$ & $.433 \pm .114$ & 22.8 \\
Mean & $.151 \pm .071$ & $.159 \pm .069$ & $.107 \pm .033$ & $-.153 \pm .015$ & $.037 \pm .105$ & $.368 \pm .085$ & 20.1 \\
\hline
\end{tabular}


together in quadrature to estimate the error in the "Net Residual" budget term. Because the two instruments agreed with one another to within $2 \%$, we consider the errors in all of the budget terms to be comparable. Even so, systematic errors due to accuracy limitations are expected to be less than $2 \mathrm{ppv}$ for both instruments, which corresponds to only $\sim 10 \%$ in relative terms. Resultant errors in mean values, derivatives, and covariances should all scale approximately with this relative error, and in fact most of the error estimates reported in Table 1 are considerably larger, so we do not expect systematic errors to dominate. As for random precision errors, drift of the TECO is declared by the manufacturer to be $<1 \mathrm{ppv} \mathrm{d}^{-1}$ (and no evidence of such a large drift is ever observed in routine calibrations.) Therefore, even the most liberal estimate of drift in the measurements would lead to $<0.3 \mathrm{ppb}$ over the course of a $7 \mathrm{~h}$ flight, corresponding to $\sim 15 \%$ of the observed daytime change, and this too exceeds our average error estimate.

\section{Results}

For the daytime flights, the observed rate of change (Table 1) averaged $-0.17 \pm .04 \mathrm{ppv} \mathrm{h}^{-1}$ which, over the course of the daylight hours results in a net ozone loss of $\sim 1.9 \pm .45 \mathrm{ppv} /$ day. Combining the mission average sources from entrainment flux (1.25 ppv/night) and advection ( $0.58 \mathrm{ppv} / \mathrm{night})$ suggests an average nighttime return of $1.8 \mathrm{ppv} / \mathrm{night}$ and a very nearly balanced diurnal cycle. Thus it appears that the photochemical destruction (and uptake by the ocean) taking place during the day is balanced in a diel sense by mean advection and entrainment from above. The ozone and virtual temperature profiles for RF06, one of the sunrise flights, are shown in Fig. 3 illustrating the three layer system and the buildup of ozone overnight due to entrainment from the buffer layer.

\subsection{Chemistry}

The chemistry component of the boundary layer budget of ozone is dominated by gas phase reactions involving $\mathrm{NO}_{\mathrm{x}}$ and $\mathrm{HO}_{\mathrm{x}}$ (Jacob 2000). The only significant source of ozone in the troposphere is via photolysis of $\mathrm{NO}_{2}$. The photolysis of ozone results in some ozone being permanently destroyed when the excited oxygen atom product, $\mathrm{O}\left({ }^{1} D\right)$, reacts with water vapor to form two hydroxyl radicals. The ozone photolysis rate constant is estimated from the National Center for Atmospheric Research (NCAR) Tropospheric Ultraviolet \& Visible (TUV) calculator using the solar zenith angle and the assumption of a cloud-free atmosphere. Inclusion of clouds will reduce both ozone production and loss terms by $\sim 5 \%$ (Voulgarakis et al. 2009). With approximately $20 \%$ of the loss going to reaction with $\mathrm{OH}$ and $\mathrm{HO}_{2}$, we expect our loss to photolysis to be overestimated by $\sim 4 \%$. During the daytime, losses are roughly triple production, leaving an expected bias on the order of $2-3 \%$. The error in the TUV calculation of the photolytic rate constant (J_O3) was assumed to be $10 \%$. To calculate the ozone loss from this $\mathrm{OH}$ production mechanism, we estimate the fraction of excited oxygen that reacts with water (the majority are simply quenched back to their ground state, $\mathrm{O}\left({ }^{3} P\right)$, which ultimately find molecular oxygen to reform ozone). For a typical PASE water vapor mixing ratio of $15 \mathrm{~g} \mathrm{~kg}^{-1}$, this fraction is approximately 0.13 .

$\mathrm{HO}_{2}$ and $\mathrm{RO}_{2}$ perturb the $\mathrm{NO}_{\mathrm{x}}$ balance by converting a molecule of $\mathrm{NO}$ to $\mathrm{NO}_{2}$ without destroying an ozone molecule in the process. Unfortunately, $\mathrm{NO}$ and $\mathrm{NO}_{2}$ are difficult to quantify in these pristine environments and were not measured during PASE; however, past observations in the area indicate NO levels below 5 ppt in the MBL [Wang et al. 2001]. We can estimate the $\mathrm{NO}_{\mathrm{x}}$ concentration by examining the residual in the ozone budget and assuming that the missing ozone production is attributable solely to $\mathrm{NO}_{\mathrm{x}}$. As expected, 

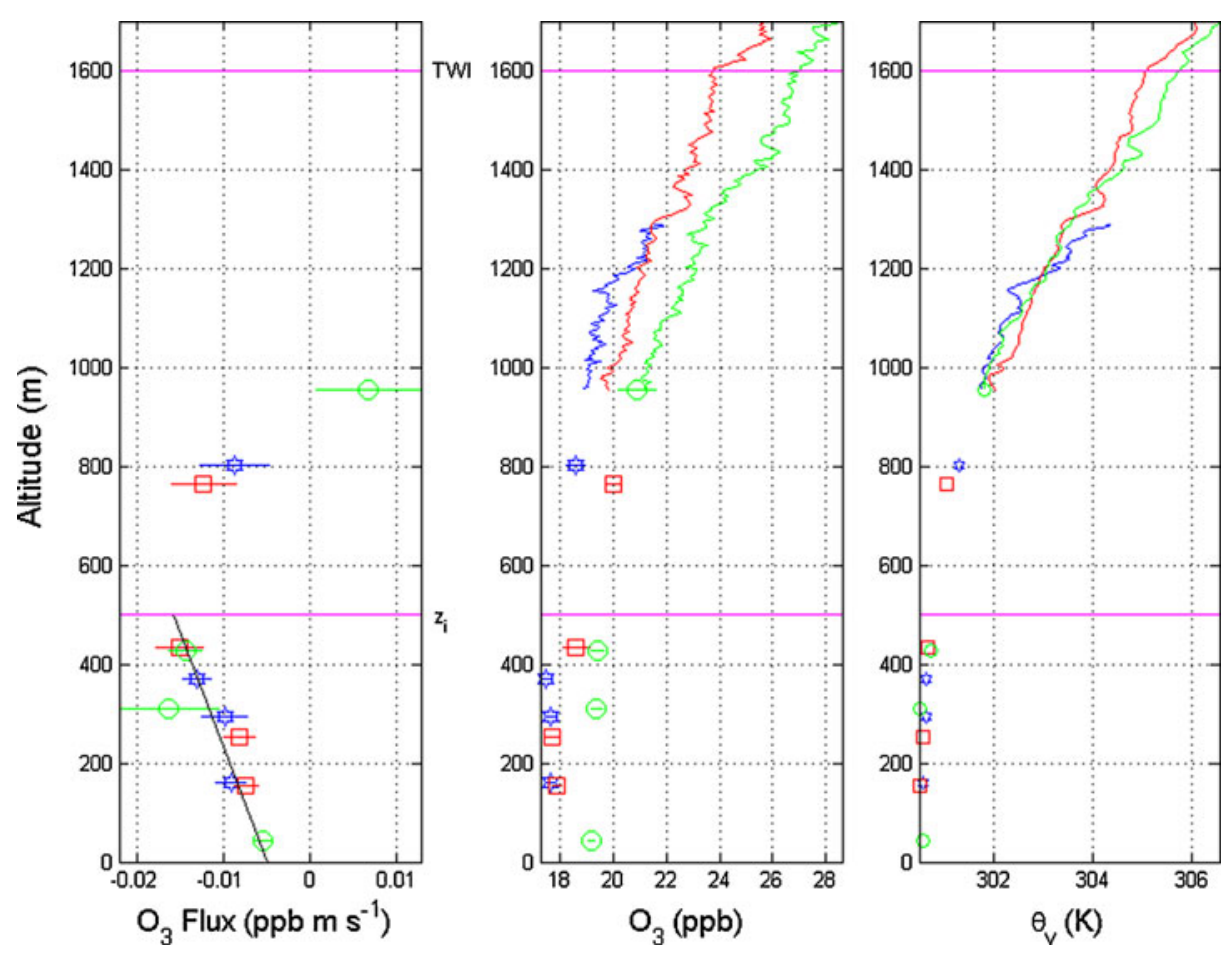

Fig. 3 Ozone flux profile for RF06 (left panel), mean ozone mixing ratio (center panel) and vertical profiles of virtual potential temperature (right panel). Mid-stack local times were 4 AM (blue), 6:30 (red), and 9 AM (green). The horizontal magenta lines represent the tops of the MBL and BuL

photolysis dominates the chemical sinks with $82 \%$ of the chemical loss (averaging $\left.0.30 \mathrm{ppv} \mathrm{h} \mathrm{h}^{-1}\right)$. The loss to $\mathrm{HO}_{2}\left(11 \%\right.$ or $0.04 \mathrm{ppv} \mathrm{h}^{-1}$ on average) is found to be considerably less than the $30 \%$ reported by Liu et al. (1983), but the PASE mission included actual measurements of $\mathrm{HO}_{2}$ compared to modeled values of the Liu et al. (1983) study. The modeled value of $\mathrm{HO}_{2}$ in the Liu study had a daily maximum of $\sim 32 \mathrm{ppt}$, substantially higher than measured during PASE ( $\sim 14$ ppt daytime average). Reaction with hydroxyl $(\mathrm{OH})$ constituted the remaining $7 \%$ of the photochemical destruction.

\subsection{Flight budgets}

Insufficient $\mathrm{O}_{3}$ and $\mathrm{OH}$ data from $\mathrm{RF} 03$, and RF07, and inadequate vertical separation on RF11 made these flights unsuitable for budget calculations. The budgets for the remaining flights (six daytime and two sunrise) are listed in Table 1. The total budgets for day and night indicate that the dynamical source of ozone to the MBL is not solely downward transport from the BuL. Instead, contributions from horizontal advection are approximately half as big as vertical transport, meaning that ozone transport from upwind continental sources is an important factor in the ozone budget of this region as suggested by de Laat and Lelieveld (2000). The typical flux profile for ozone in the MBL (Fig. 3) indicates downward flux at the top in conjunction with a smaller downward flux at the bottom (i.e. deposition to the sea surface). This results in a budget contribution that is positive for nearly all of the PASE flights. The exception, RF02, was initially a surprise; however, further 
examination revealed that the mixing ratio in the MBL (19.4 ppb) was actually higher than the overlying $\mathrm{BuL}(17.8 \mathrm{ppb})$. Consequently, turbulent mixing was transporting ozone upward into the $\mathrm{BuL}$ on this flight. The inversion of the usual vertical structure is probably the result of differential horizontal advection, and in fact, the MBL advection on RF02 was more than triple the mission average and far exceeded the contribution from vertical transport.

Because of the absence of runway lighting at the Christmas Island airport, flights were scheduled such that the airplane always had enough fuel during the hours of darkness to divert to Hawaii if there was an exigent need to land. Because of this restriction, night operations could not begin until $\sim 2 \mathrm{AM}$, leaving only 4 h of darkness. The two sunrise research flights (RF06 \& RF13) therefore included only 1 entire stack in darkness. The second stack straddled sunrise, and the third stack was conducted completely in daylight. Safety rules precluded low level legs in darkness, so the first two stacks did not include surface layer legs. Because of this, the sunrise flight budgets presented include only the legs occurring after sunrise. Both $\mathrm{OH}$ and $\mathrm{HO}_{2}$ were not measured on RF06 because of instrument issues and therefore diurnally extrapolated values from the other flights were used instead.

A survey of results from various MBL ozone budget estimates made over the past 25 years is shown in Table 2. Among these studies, direct measurement of the entrainment and deposition fluxes are only reported by Kawa and Pearson (1989) during the original DYCOMS-I experiment. Their results appeared to be complicated by mesoscale gradients in ozone and a sampling strategy that did not adequately estimate the advective contributions to the budget.

\subsection{Ocean uptake}

Considerable progress has been made in understanding the physics and chemistry of ozone uptake by the ocean since the enclosure experiments of Aldaz (1969) brought it to the attention of the atmospheric chemistry community. Dry deposition to the ocean surface is observed to be much slower than over land surfaces (Galbally and Roy 1980) yet much faster than its meager solubility would imply (Garland et al. 1980; Schwartz 1992). More recently, Fairall et al. (2007) laid out a sound theoretical framework for estimating ozone deposition rates based on the standard three resistance model: $1 / v_{d}=R_{a}+R_{b}+R_{c}$, where $v_{d}$ is the total dry deposition velocity, $\mathrm{R}_{\mathrm{a}}$ is the aerodynamic resistance due to micrometeorological

Table 2 Survey of ozone destruction rates. Negative values indicate net ozone production

\begin{tabular}{lllll}
\hline Reference & Region & $\mathrm{NO}(\mathrm{ppt})$ & $\begin{array}{l}\mathrm{Net}_{3} \\
\text { Loss }\left(\mathrm{d}^{-1}\right)\end{array}$ & {$\left[\mathrm{O}_{3}\right](\mathrm{ppb})$} \\
\hline Liu et al. (1983) & & & 0.13 & 15 \\
Kawa and Pearson (1989) & Equatorial Pacific & 3.7 & 0.1 & 29 \\
Johnson et al. (1990) & Indian \& Pacific & Unknown & 0.1 to 0.2 & $10-20$ \\
Thompson et al. (1993) & Equatorial Pacific & 1.3 & 0.13 & 10 \\
Paluch et al. (1994) & E. Atlantic & Unknown & $0.14-0.40$ & 20 \\
Noone et al. (1996) & N. Atlantic & Unknown & -0.04 & 18.5 \\
Heikes et al. (1996) & S. Atlantic & $<5$ & 0.08 & 27 \\
Clarke et al. (1996) & Equatorial Pacific & Unknown & 0.13 & 14.5 \\
Singh et al. (1996) & W. Pacific & 5.5 & 0.23 & 10 \\
Ayers et al. (1997) & S. Pacific & 2 & 0.12 & 15.4 \\
Read et al. (2008) & Tropical Atlantic & 3.2 & 0.23 & 30.5 \\
This study & Equatorial Pacific & 2.7 & 0.18 & 17.5 \\
\hline
\end{tabular}


conditions, $\mathrm{R}_{\mathrm{b}}$ represents the resistance provided by molecular diffusion across the thin laminar layer adjacent to the ocean surface, and $\mathrm{R}_{\mathrm{c}}$ represents the combined resistance of turbulent transport, molecular diffusion, and irreversible chemical reaction in the ocean. The deposition velocity observed during PASE averaged $0.24( \pm 0.14) \mathrm{mm} \mathrm{s}^{-1}$, very similar to the mean value of $0.26 \mathrm{~mm} \mathrm{~s}^{-1}$ reported during DYCOMS-I (Kawa and Pearson 1989) for comparable wind stress (the average friction velocity during DYCOMS-I was $0.22 \mathrm{~ms}^{-1}$ compared to $0.24 \mathrm{~ms}^{-1}$ during PASE.) We further analyzed the ozone flux data from DYCOMS-II flown off the coast of Baja California in July 2001 (Faloona et al. 2005), and found a mean deposition velocity of $0.39 \pm .15 \mathrm{~mm} \mathrm{~s}^{-1}$ in the marine stratocumulus environment. The ozone deposition velocity over the Gulf of Mexico during the summer of 1980 was estimated between 0.50 and $0.57 \mathrm{~mm} \mathrm{~s}^{-1}$ (Lenschow et al. 1982). Similar dry deposition rates have been observed off the coast of Ireland (McVeigh et al. 2010) and modeled in the Central Pacific (Ganzeveld et al. 2009); however observations indicate considerable variability. Using the formulation outlined in Fairall et al. (2007) we calculate that the combined aerodynamic and sublayer resistances $\left(\mathrm{R}_{\mathrm{a}}+\mathrm{R}_{\mathrm{b}}\right)$ are less than $5 \%$ of the overall resistance, and that the average ozone ocean reactivity (defined as an equivalent first order reaction rate) was $\sim 50 \mathrm{~s}^{-1}$. This value corresponds to a surface resistance of around $4,000 \mathrm{sm}^{-1}$, comparable to the results of Kawa and Pearson (1989), but about $30 \%$ higher than July averages for the region modeled by Ganzeveld et al. (2009).

\section{4 $\mathrm{NO}_{\mathrm{x}}$ estimation}

The PASE ozone budget consistently indicates a small source of ozone in the MBL (average 'Net Residual' column of Table 1). Only the chemical loss terms have been included in Table 1, while the production terms (which depend on NO) have been excluded, primarily because $\mathrm{NO}_{\mathrm{x}}$ was not measured during PASE. Given the known reaction rates for $\mathrm{HO}_{2}$ and $\mathrm{RO}_{2}$ reacting with $\mathrm{NO}$, the budget residual can be used to estimate how much NO is needed to balance the overall ozone budget on each flight. The 'Net Residual' column in Table 1 shows an average ozone production of $117 \mathrm{ppt} \mathrm{h}^{-1}$ is required to balance the budget for the daytime flights. The average concentrations of $\mathrm{HO}_{2}$ and $\mathrm{RO}_{2}$ for the daytime flights were $14 \mathrm{ppt}$ and $29 \mathrm{ppt}$ respectively. Therefore, for $1 \mathrm{ppt}$ of $\mathrm{NO}$, the $\mathrm{O}_{3}$ production is $\sim 30 \mathrm{ppt} \mathrm{h}^{-1}$, such that the estimated NO mixing ratio is $\sim 3.9 \pm 3.0 \mathrm{ppt}$, in agreement with the data reported by Wang et al. (2001) for the same region. A previous study of the $\mathrm{NO}_{\mathrm{x}}$ budget in the equatorial Pacific around local noon found NO values between 2.9 and 5.7 ppt (Liu et al. 1983). During PEM Tropics A, which occurred at a similar time of year (August-October), the mean NO mixing ratio was $\sim 2$ ppt (Staudt et al. 2003). The daytime photostationary state $\mathrm{NO}_{2} / \mathrm{NO}$ ratio in the PASE environment (considering photolysis of $\mathrm{NO}_{2}$, reaction of $\mathrm{NO}$ with $\mathrm{O}_{3}, \mathrm{HO}_{2}, \mathrm{RO}_{2}$ and $\mathrm{OH}$ ) varied between 1.8 and 2.8 with a mean value of $\sim 2$ throughout the middle of the day. Thus the estimate of $3.9 \pm 3.0 \mathrm{ppt}$ NO implies levels of $\mathrm{NO}_{2}$ to be $7.8 \pm 6.0 \mathrm{ppt}$, and total $\mathrm{NO}_{\mathrm{x}}$ at $11.7 \pm 9.0 \mathrm{ppt}$.

Reactive bromine has been potentially implicated in the remote MBL ozone balance via two catalytic cycles (Hausmann and Platt 1994; von Glasow et al. 2004):

$$
\text { (1) } \begin{aligned}
& \mathrm{BrO}+\mathrm{BrO} \rightarrow 2 \mathrm{Br}+\mathrm{O}_{2} \\
& \mathrm{Br}+\mathrm{O}_{3} \rightarrow \mathrm{BrO}
\end{aligned}
$$


The rate limiting steps in the two cycles are the reactions of $\mathrm{BrO}$ with itself and with $\mathrm{HO}_{2}$. The rate of ozone destruction from these two cycles can be estimated as a function of $\mathrm{BrO}$ by $k_{1}[\mathrm{BrO}]^{2}+k_{2}[\mathrm{BrO}]\left[\mathrm{HO}_{2}\right]$, with $k_{1}=3.2 \times 10^{-12} \mathrm{~cm}^{3} \mathrm{mlc}^{-1} \mathrm{~s}^{-1}$ and $k_{2}=2.1 \times$ $10^{-11} \mathrm{~cm}^{3} \mathrm{mlc}^{-1} \mathrm{~s}^{-1}$ (Sander et al. 2006). Given the observed midday $\mathrm{HO}_{2}$ mixing ratio of $14 \mathrm{ppt}$, and its faster reaction rate with $\mathrm{BrO}$, the second catalytic cycle should be an order of magnitude larger sink of ozone than the first for $\mathrm{BrO}$ mixing ratios on the order of $10 \mathrm{ppt}$ or less. The catalytic destruction of ozone from bromine chemistry can thus be approximated by $k_{2}[\mathrm{BrO}]\left[\mathrm{HO}_{2}\right]$, which equates to $\sim 0.026 \mathrm{ppv} \mathrm{h}^{-1}$ for each $1 \mathrm{ppt}$ of BrO. Thus, in terms of the above $\mathrm{NO}_{\mathrm{x}}$ estimate, each $1 \mathrm{ppt}$ of $\mathrm{BrO}$ could effectively mask the ozone production from 1 ppt of additional $\mathrm{NO}$ in the ozone budget.

\subsection{Long term trend}

It appears from Table 1 that the photochemical production of ozone is actually growing over the course of the month during the experiment. Figure 4 shows the correlation between ozone production and the day of the experiment $\left(R^{2}=0.74\right)$ and indicates that the chemical production of ozone in the PASE region roughly trippled over the course of the experiment. During that same time, measurements of carbon monoxide (CO) increased from $\sim 58 \mathrm{ppv}$ to $\sim 74 \mathrm{ppv}$, and observations of bulk aerosol nitrate also increased (R. Simpson, unpublished data) suggesting that the aircraft may have been sampling more anthropogenically influenced air later in the experiment. It is clear that any subsequent attempt at a tropical MBL budget for ozone must include simultaneous measurements of $\mathrm{NO}$ or $\mathrm{NO}_{2}$, although quantification down to the inferred levels of 2-6 ppt still present a significant challenge to the airborne measurement community.

\subsection{Buffer layer budget}

There were not enough legs flown in the buffer layer during any given flight to construct a flight-by-flight budget, therefore we estimate a long-term BuL budget for the entire mission. Horizontal advection is estimated by multiplying the upwind horizontal gradient

Fig. 4 Ozone budget missing source (gross photochemical production) plotted as a function of the day of the experiment. $R^{2}=0.74$. The $p$-value for this correlation is 0.03 (indicating a $3 \%$ probability that this trend could have resulted from random data)

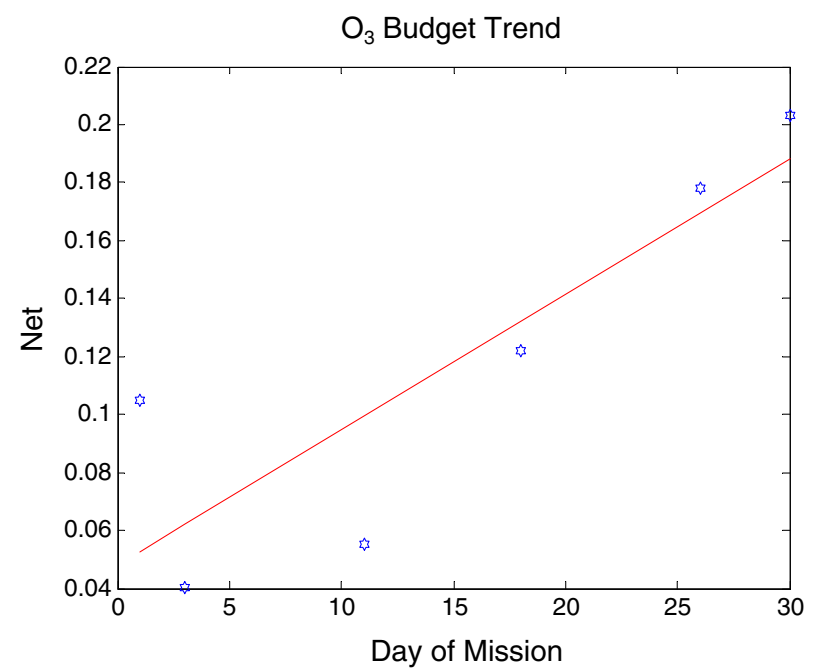


derived from TOMS Tropospheric $\mathrm{O}_{3}$ (Ziemke et al. 2006) by the mean wind $\left(10 \mathrm{~ms}^{-1}\right)$. For the BuL, which was observed to have a mean depth of $800 \mathrm{~m}$, we observed a mean $\mathrm{O}_{3}$ mixing ratio of 21.3 ppv. From the MBL budget, the average flux of $\mathrm{O}_{3}$ from the BuL into the MBL is $0.014 \mathrm{ppv} \mathrm{m} \mathrm{s}^{-1}$. Assuming a long-term steady state in the $\mathrm{O}_{3}$ concentration, and a net destruction estimated from the photochemical lifetime determined for the MBL, the influx across the trade wind inversion can be estimated. A summary of the BuL budget terms and their methods of estimation are shown in Table 3.

From the buffer layer budget we estimate a net influx of ozone from the free troposphere that is roughly twice as large as the flux into the MBL.

Given the flux and the difference in ozone between the $\mathrm{BuL}$ and the FT, we further estimate the entrainment velocity, $\nu_{e}$, across the TWI by the relationship: Flux $=v_{e} \cdot\left(O_{3-B u L}-O_{3-F T}\right)$. Using the legs flown above the TWI, we estimate the mean $\mathrm{O}_{3}$ mixing ratio in the lower FT as $25.4 \pm 2.7 \mathrm{ppb}$. So with a jump of $4.1 \pm 3.0 \mathrm{ppv}$ and a flux of $-2.7 \pm 1.8 \mathrm{ppv} \mathrm{cm} \mathrm{s}^{-1}$, the entrainment velocity is $0.66 \pm 0.38 \mathrm{~cm} \mathrm{~s}^{-1}$. As a very rough check on this vertical transport rate, the mission averaged subsidence rates were calculated from NCEP reanalysis data (courtesy of NOAA/ESRL Physical Sciences Division) and found to range from $\sim 0.4$ $0.5 \mathrm{~cm} \mathrm{~s}^{-1}$ at $850 \mathrm{mb}$. So the rate of subsidence approximately matches the entrainment in accord with the long-term steady-state assumption of the method. Previous attempts to measure entrainment of FT air into the BuL suffered from similarly large uncertainties. For example, during ACE1, the FT-to-BuL entrainment rates estimated near Tasmania varied from near 0 at the beginning of the experiment to $0.8 \mathrm{~cm} \mathrm{~s}^{-1}$ at the end (Russell et al. 1998). Nevertheless, given the lack of BuL sampling during PASE and the overall success of the above methodology, there is reason to believe that a flight strategy focused more closely on the $\mathrm{BuL}$ would yield more accurate estimates of this important vertical mixing parameter.

\section{Conclusion}

Ozone, its vertical turbulent fluxes, and its horizontal gradients were measured simultaneously in the remote equatorial pacific MBL during the summer of 2007. The mean boundary layer ozone mixing ratio from all eight flights analyzed was $18.8 \pm 1.9 \mathrm{ppb}$. Photochemical ozone destruction was dominated by photolysis $(82 \%)$, followed by reaction with $\mathrm{HO}_{2}(11 \%)$ and $\mathrm{OH}(7 \%)$. Diurnally averaged ocean uptake was found to be about one-third as large as the net photochemical sink, removing $0.8 \mathrm{ppb} \mathrm{d}^{-1}$ and controlled predominantly by an ocean reactivity of $\sim 50 \mathrm{~s}^{-1}$. After accounting for dynamics (advection

Table 3 Buffer layer (BuL) budget of ozone. The advection estimate is the product of the observed mean wind speed and the upwind gradient derived from the TOMS tropospheric 3 product. The flux of ozone from the FT into the BuL is assumed to balance the budget of all the other terms

\begin{tabular}{llc}
\hline Term & Calculation & Result \\
\hline $\mathrm{O}_{3}$ Loss to MBL & Flux @ $\mathrm{z}_{\mathrm{i}} /$ BuL Thickness & $-0.061 \pm .060 \mathrm{ppv} \mathrm{h}^{-1}$ \\
Mean BuL O & Average all BuL Legs & $21.3 \pm 2.13 \mathrm{ppv}$ \\
Photochemical Lifetime & MBL Budget & $157 \pm 53.0 \mathrm{~h}$ \\
Net Photochemical Destruction & BuL Mixing Ratio/Lifetime & $-0.135 \pm 0.047 \mathrm{ppv} \mathrm{h}^{-1}$ \\
Advection & TOMS Tropospheric O $\mathrm{H}_{3}$ & $+0.076 \pm 0.020 \mathrm{ppv} \mathrm{h}^{-1}$ \\
$\mathrm{O}_{3}$ Influx from FT & Flux to MBL-Destruction-Advection & $+0.120 \pm 0.079 \mathrm{ppv} \mathrm{h}^{-1}$ \\
Estimated FT Flux across TWI & FT Source * BuL Depth & $-0.027 \pm 0.018 \mathrm{ppb} \mathrm{ms}^{-1}$ \\
\hline
\end{tabular}


and vertical transport) and photochemical and deposition losses, a concomitant production rate was estimated as the residual in the budget. Gross photochemical production averaged $0.12 \mathrm{ppv} \mathrm{h}^{-1}$ for the daytime flights yielding an estimated NO mixing ratio of $3.9 \pm 3.0 \mathrm{ppt}$ and a total $\mathrm{NO}_{\mathrm{x}}$ at $11.7 \pm 9.1$ ppt. The estimate of $\mathrm{NO}$, however, could be influenced by the presence of $\mathrm{BrO}$, which would result from ozone destruction in a nearly one-to-one manner (1 ppt $\mathrm{BrO} \sim 1 \mathrm{ppt} \mathrm{NO}$ ). In the net, daytime photochemistry destroyed $0.25 \mathrm{ppv} \mathrm{h}^{-1}$, implying an overall photochemical ozone loss of $\sim 2.8 \mathrm{ppv} \mathrm{d}^{-1}$. Horizontal advection, while bringing in lower ozone on two of the eight flights, was in general a significant source to the region, averaging about one-half the source from downward mixing from the BuL. By studying the long-term project budget of ozone in the BuL the entrainment velocity across the TWI was estimated to be $0.66 \pm 0.38 \mathrm{~cm} \mathrm{~s}^{-1}$.

Acknowledgements The National Center for Atmospheric Research is sponsored by the National Science Foundation. This work was made possible through a grant from the Atmospheric Chemistry Program of the National Science foundation (ATM-0627227).

The QuikSCAT Ocean Winds data were obtained from the Physical Oceanography Distributed Active Archive Center (PO.DAAC) at the NASA Jet Propulsion Laboratory, Pasadena, CA. http://podaac.jpl.nasa.gov.

Aircraft navigation data and atmospheric state variables provided by NCAR/EOL under sponsorship of the National Science Foundation (http://data.eol.ucar.edu/).

Open Access This article is distributed under the terms of the Creative Commons Attribution Noncommercial License which permits any noncommercial use, distribution, and reproduction in any medium, provided the original author(s) and source are credited.

\section{References}

Aldaz, L.: Flux measurements of atmospheric ozone over land water. J. Geophys. Res. 74, 6943-6946 (1969) Ayers, G.P., Granek, H., Boers, R.: Ozone in the marine boundary layer at cape grim: Model simulation. J. Atmos. Chem. 27, 179-195 (1997)

Cantrell, C.A., Edwards, G.D., Stephens, S., Mauldin, L., Kosciuch, E., Zondlo, M., Eisele, F.: Peroxy radical observations using chemical ionization mass spectrometry during topse. J. Geophys. Res. Atmos. 108 (2003a). doi:10.1029/2002jd002715

Cantrell, C.A., Edwards, G.D., Stephens, S., Mauldin, R.L., Zondlo, M.A., Kosciuch, E., Eisele, F.L., Shetter, R.E., Lefer, B.L., Hall, S., Flocke, F., Weinheimer, A., Fried, A., Apel, E., Kondo, Y., Blake, D.R., Blake, N.J., Simpson, I.J., Bandy, A.R., Thornton, D.C., Heikes, B.G., Singh, H.B., Brune, W.H., Harder, H., Martinez, M., Jacob, D.J., Avery, M.A., Barrick, J.D., Sachse, G.W., Olson, J.R., Crawford, J.H., Clarke, A.D.: Peroxy radical behavior during the transport and chemical evolution over the pacific (trace-p) campaign as measured aboard the nasa p-3b aircraft. J. Geophys. Res. Atmos. 108 (2003b). doi:10.1029/ 2003jd003674

Clarke, A.D., Li, Z., Litchy, M.: Aerosol dynamics in the equatorial pacific marine boundary layer: Microphysics, diurnal cycles and entrainment. Geophys. Res. Lett. 23, 733-736 (1996)

Conley, S.A., Faloona, I., Miller, G.H., Lenschow, D.H., Blomquist, B., Bandy, A.: Closing the dimethyl sulfide budget in the tropical marine boundary layer during the pacific atmospheric sulfur experiment. Atmos. Chem. Phys. 9, 8745-8756 (2009)

Crutzen, P.J., Lawrence, M.G., Poschl, U.: On the background photochemistry of tropospheric ozone. Tellus. Dyn. Meteorol. Oceanogr. 51, 123-146 (1999)

de Arellano, J.V.G., Dosio, A., Vinuesa, J.F., Holtslag, A.A.M., Galmarini, S.: The dispersion of chemically reactive species in the atmospheric boundary layer. Meteorol. Atmos. Phys. 87, 23-38 (2004). doi:10.1007/s00703-003-0059-2

de Laat, A.T.J., Lelieveld, J.: Diurnal ozone cycle in the tropical and subtropical marine boundary layer. J. Geophys. Res. Atmos. 105, 11547-11559 (2000)

Eastman, J.A., and Stedman, D.H.: Fast response sensor for ozone eddy-correlation flux measurements. Atmos. Environ. 11, 1209-1211 (1977). doi:10.1016/0004-6981(77)90097-x 
Fairall, C.W., Helmig, D., Ganzeveld, L., Hare, J.: Water-side turbulence enhancement of ozone deposition to the ocean. Atmos. Chem. Phys. 7, 443-451 (2007)

Faloona, I., Lenschow, D.H., Campos, T., Stevens, B., van Zanten, M., Blomquist, B., Thornton, D., Bandy, A., Gerber, H.: Observations of entrainment in eastern pacific marine stratocumulus using three conserved scalars. J. Atmos. Sci. 62, 3268-3285 (2005)

Faloona, I., Conley, S.A., Blomquist, B., Clarke, A.D., Kapustin, V., Howell, S., Lenschow, D.H., Bandy, A.R.: Sulfur dioxide in the tropical marine boundary layer: Dry deposition and heterogeneous oxidation observed during the pacific atmospheric sulfur experiment. J. Atmos. Sci. 63, 13-32 (2009). doi:10.1007/s10874-010-9155-0

Galbally, I.E., Roy, C.R.: Destruction of ozone at the earths surface. Q. J. R. Meteorol. Soc. 106, 599-620 (1980)

Ganzeveld, L., Lelieveld, J.: Dry deposition parameterization in a chemistry general-circulation model and its influence on the distribution of reactive trace gases. J. Geophys. Res. Atmos. 100, 20999-21012 (1995)

Ganzeveld, L., Helmig, D., Fairall, C.W., Hare, J., Pozzer, A.: Atmosphere-ocean ozone exchange: A global modeling study of biogeochemical, atmospheric, and waterside turbulence dependencies. Global Biogeochem. Cy. 23 (2009). doi:10.1029/2008gb003301

Garland, J.A., Elzerman, A.W., Penkett, S.A.: The mechanism for dry deposition of ozone to seawater surfaces. J. Geophys. Res. Oceans Atmos. 85, 7488-7492 (1980)

Hansen, J., Sato, M., Kharecha, P., Russell, G., Lea, D.W., Siddall, M.: Climate change and trace gases. Phil. Trans. Math Phys. Eng. Sci. 365, 1925-1954 (2007). doi:10.1098/rsta.2007.2052

Hausmann, M., Platt, U.: Spectroscopic measurement of bromine oxide and ozone in the high arctic during polar sunrise experiment 1992. J. Geophys. Res. Atmos. 99, 25399-25413 (1994)

Heikes, B., Lee, M.H., Jacob, D., Talbot, R., Bradshaw, J., Singh, H., Blake, D., Anderson, B., Fuelberg, H., Thompson, A.M.: Ozone, hydroperoxides, oxides of nitrogen, and hydrocarbon budgets in the marine boundary layer over the south atlantic. J. Geophys. Res. Atmos. 101, 24221-24234 (1996)

Hornbrook, R.S., Crawford, J.H., Edwards, G.D., Goyea, O., Mauldin III, R.L., Olson, J.S., Cantrell, C.A.: Measurements of tropospheric ho2 and ro2 by oxygen dilution modulation and chemical ionization mass spectrometry. Atmos. Meas. Tech. Discuss. 4, 385-442 (2011)

Horowitz, L.W., Walters, S., Mauzerall, D.L., Emmons, L.K., Rasch, P.J., Granier, C., Tie, X.X., Lamarque, J. F., Schultz, M.G., Tyndall, G.S., Orlando, J. J., Brasseur, G.P.: A global simulation of tropospheric ozone and related tracers: Description and evaluation of mozart, version 2. J. Geophys. Res. Atmos. 108 (2003). doi:10.1029/2002jd002853

Jacob, D.J.: Heterogeneous chemistry and tropospheric ozone. Atmos. Environ. 34, 2131-2159 (2000)

Jacob, D.J., Heikes, B.G., Fan, S.M., Logan, J.A., Mauzerall, D.L., Bradshaw, J.D., Singh, H.B., Gregory, G. L., Talbot, R.W., Blake, D.R., Sachse, G.W.: Origin of ozone and nox in the tropical troposphere: A photochemical analysis of aircraft observations over the south atlantic basin. J. Geophys. Res. Atmos. 101, 24235-24250 (1996)

Johnson, J.E., Gammon, R.H., Larsen, J., Bates, T.S., Oltmans, S.J., Farmer, J.C.: Ozone in the marine boundary-layer over the pacific and Indian oceans - latitudinal gradients and diurnal cycles. J. Geophys. Res. Atmos. 95, 11847-11856 (1990)

Kawa, S.R., Pearson, R.: Ozone budgets from the dynamics and chemistry of marine stratocumulus experiment. J. Geophys. Res. Atmos. 94, 9809-9817 (1989)

Kolev, N.I., Savov, P.B., Kaprielov, B.K., Grigorieva, V.N., Kolev, I.N.: Influence of the boundary layer development on the ozone concentration over an urban area. Int. J. Remote. Sens. 29, 1877-1902 (2008). doi:10.1080/01431160701355298

Krol, M.C., Molemaker, M.J., de Arellano, J.V.G.: Effects of turbulence and heterogeneous emissions on photochemically active species in the convective boundary layer. J. Geophys. Res. Atmos. 105, 6871-6884 (2000)

Lenschow, D.H., Wyngaard, J.C., Pennell, W.T.: Mean-field and 2nd-moment budgets in a baroclinic, convective boundary-layer. J. Atmos. Sci. 37, 1313-1326 (1980)

Lenschow, D.H., Pearson, R., Stankov, B.B.: Measurements of ozone vertical flux to ocean and forest. J. Geophys. Res. Atmos. 87, 8833-8837 (1982)

Liu, S.C., McFarland, M., Kley, D., Zafiriou, O., Huebert, B.: Tropospheric nox and o3 budgets in the equatorial pacific. J. Geophys. Res. Oceans Atmos. 88, 1360-1368 (1983)

Mauldin, R.L., Cantrell, C.A., Zondlo, M.A., Kosciuch, E., Ridley, B. A., Weber, R., Eisele, F.E.: Measurements of $\mathrm{OH}, \mathrm{H} 2 \mathrm{SO} 4$, and MSA during tropospheric ozone production about the spring equinox (topse). J. Geophys. Res. Atmos. 108 (2003). doi:10.1029/2002jd002295

McVeigh, P., O’Dowd, C., Berresheim, H.: Eddy correlation measurements of ozone fluxes over coastal waterswest of Ireland. Adv. Meteorol. 2010, 7 (2010)

Noone, K.J., Schillawski, R.D., Kok, G.L., Bretherton, C.S., Huebert, B.J.: Ozone in the marine atmosphere observed during the atlantic stratocumulus transition experiment marine aerosol and gas exchange. J. Geophys. Res. Atmos. 101, 4485-4499 (1996) 
Paluch, I.R., Lenschow, D.H., Siems, S., McKeen, S., Kok, G.L., Schillawski, R.D.: Evolution of the subtropical marine boundary-layer-comparison of soundings over the eastern pacific from fire and harp. J. Atmos. Sci. 51, 1465-1479 (1994)

Pearson, R., Jr., Stedman, D.H.: Instrumentation for fast response ozone measurements from aircraft. Atmospheric Technology, National Center for Atmospheric Research 12, 51-55 (1980)

Piotrowicz, S.R., Boran, D.A., Fischer, C.J.: Ozone in the boundary-layer of the equatorial pacific-ocean. J. Geophys. Res. Atmos. 91, 3113-3119 (1986)

Read, K.A., Mahajan, A.S., Carpenter, L.J., Evans, M.J., Faria, B.V.E., Heard, D.E., Hopkins, J.R., Lee, J.D., Moller, S.J., Lewis, A.C., Mendes, L., McQuaid, J.B., Oetjen, H., Saiz-Lopez, A., Pilling, M.J., Plane, J. M.C.: Extensive halogen-mediated ozone destruction over the tropical atlantic ocean. Nature 453, 12321235 (2008). doi:10.1038/nature07035

Ridley, B.A., Grahek, F.E., Walega, J.G.: A small, high-sensitivity, medium-response ozone detector suitable for measurements from light aircraft. J. Atmos. Ocean Tech. 9, 142-148 (1992)

Russell, L.M., Lenschow, D.H., Laursen, K.K., Krummel, P.B., Siems, S.T., Bandy, A.R., Thornton, D.C., Bates, T.S.: Bidirectional mixing in an ACE 1 marine boundary layer overlain by a second turbulent layer. J. Geophys. Res. Atmos. 103, 16411-16432 (1998)

Sander, S., Golden, D., Kurylo, M., Moortgat, G., Wine, P.: Chemical kinetics and photochemical data for use in atmospheric studies. JPL Publication 06, 26 (2006)

Schwartz, S.: Factors governing dry deposition of gasses to surface water. In: Schwartz, S.E. (ed.) Precipitation, Scavenging \& Atmosphere-Surface Exchange, pp. 789-801. Hemisphere Publishing Corp., Taylor \& Francis Group, Washington (1992)

Singh, H.B., Gregory, G.L., Anderson, B., Browell, E., Sachse, G.W., Davis, D.D., Crawford, J., Bradshaw, J. D., Talbot, R., Blake, D.R., Thornton, D., Newell, R., Merrill, J.: Low ozone in the marine boundary payer of the tropical pacific ocean: Photochemical loss, chlorine atoms, and entrainment. J. Geophys. Res. Atmos. 101, 1907-1917 (1996)

Staudt, A.C., Jacob, D.J., Ravetta, F., Logan, J.A., Bachiochi, D., Krishnamurti, T.N., Sandholm, S., Ridley, B., Singh, H.B., Talbot, B.: Sources and chemistry of nitrogen oxides over the tropical pacific. J. Geophys. Res. Atmos. 108, 8239 (2003). doi:10.1029/2002jd002139

Thompson, A.M., Johnson, J.E., Torres, A.L., Bates, T.S., Kelly, K.C., Atlas, E., Greenberg, J.P., Donahue, N. M., Yvon, S.A., Saltzman, E.S., Heikes, B.G., Mosher, B.W., Shashkov, A.A., Yegorov, V.I.: Ozone observations and a model of marine boundary-layer photochemistry during saga-3. J. Geophys. Res. Atmos. 98, 16955-16968 (1993)

von Glasow, R., Sander, R., Bott, A., Crutzen, P. J.: Modeling halogen chemistry in the marine boundary layer-1. Cloud-free MBL. J. Geophys. Res. Atmos. 107 (2002). doi:10.1029/2001jd000942

von Glasow, R., von Kuhlmann, R., Lawrence, M.G., Platt, U., Crutzen, P.J.: Impact of reactive bromine chemistry in the troposphere. Atmos. Chem. Phys. 4, 2481-2497 (2004)

Voulgarakis, A., Wild, O., Savage, N.H., Carver, G.D., Pyle, J.A.: Clouds, photolysis and regional tropospheric ozone budgets. Atmos. Chem. Phys. 9, 8235-8246 (2009)

Wang, Y.H., Liu, S.C., Wine, P.H., Davis, D.D., Sandholm, S.T., Atlas, E.L., Avery, M.A., Blake, D.R., Blake, N.J., Brune, W.H., Heikes, B.G., Sachse, G.W., Shetter, R.E., Singh, H.B., Talbot, R.W., Tan, D.: Factors controlling tropospheric $\mathrm{o}-3, \mathrm{OH}$, nox and $\mathrm{SO} 2$ over the tropical pacific during pem-tropics b. J. Geophys. Res. Atmos. 106, 32733-32747 (2001)

Wyngaard, J.C.: Turbulence in the atmosphere, 1 ed., Cambridge University Press, pp. 406 (2010)

Yang, X., Cox, R.A., Warwick, N.J., Pyle, J.A., Carver, G.D., O'Connor, F. M., Savage, N.H.: Tropospheric bromine chemistry and its impacts on ozone: A model study. J. Geophys. Res. Atmos. 110 (2005). doi:10.1029/2005jd006244

Ziemke, J.R., Chandra, S., Duncan, B.N., Froidevaux, L., Bhartia, P. K., Levelt, P.F., Waters, J.W.: Tropospheric ozone determined from aura omi and mls: Evaluation of measurements and comparison with the global modeling initiative's chemical transport model. J. Geophys. Res. Atmos. 111 (2006). doi:10.1029/2006jd007089 